\title{
THE IMMEDIATE TERM EFFECT OF CHEWING MESWAK (SALVADORA PERSICA) ON FLOW RATE AND PH OF WHOLE SALIVA
}

N.M. Hairuddin, R.A. Jalil. The immediate term effect of chewing meswak (Salvadora persica) on flow rate and $\mathrm{pH}$ of whole saliva. Annal Dent Univ Malaya 2000; 7: $6-10$.

\section{ABSTRACT}

The objective of this study was to determine the effect chewing of two differently sized commercially available meswak might have on flow rate and $\mathrm{pH}$ of whole saliva. Twenty subjects participated in this study. They were distributed into two groups (A and B). Subjects in both groups $A$ and $B$ were asked to first chew on either a sized $m_{1} 1$ or $\|_{2}$ cotton roll followed by the chewing of an equivalent sized piece of meswak (approximately $5 \mathrm{~mm}$. and $10 \mathrm{~mm}$. diameter) respectively.

For subjects in group $\mathrm{A}$, no differences in mean flow rate was seen after both the chewing regimes. In group B however, the increase in mean flow rate after the chewing of meswak compared to cotton roll was statistically significant at $p<0.05$. Statistically significant lower values for $\mathrm{pH}$ were registered after the chewing of meswak compared to cotton roll in both groups $\mathrm{A}$ and $\mathrm{B}$ at $\mathrm{p}<0.05$ and $\mathrm{p}<0.01$ respectively.

Results of this study suggest that plants used as chewing sticks may have the potential of both increasing the flow rate and reducing the $\mathrm{pH}$ of saliva. Further studies have to be carried out to ascertain the therapeutic benefits of using meswak as an anti-plaque agent.

Key words: saliva, xerostomia, flow rate, $\mathrm{pH}$.

\section{INTRODUCTION}

The importance of saliva in the prevention of various oral diseases is substantiated by the clinical observation that rampant caries, gingivitis and soreness of the oral mucosa characterize xerostomia (1). The treatment of xerostomia is designed to either eliminate the cause or causes of these conditions or if this is not possible to alleviate the patients symptoms and clinical signs. Masticatory stimuli, chemical stimuli and drugs have been used to promote salivation. Patients should be encouraged to consume foods which require mastication. Chewing gum is an effective sialogogue however, because of the increased risk of dental caries only the sugarless variety of gum should be used. One study has shown that the frequent chewing of sugarless gum for a period of two weeks increased the output of stimulated parotid saliva and increased the $\mathrm{pH}$ and buffer capacity of whole and parotid saliva (2).

The use of chewing sticks to enhance salivary secretion in the management of xerostomia has not been explored. The most widely used chewing stick is the
Original Article

N.M. Hairuddin ${ }^{1}$ and R.A. Jalil ${ }^{2}$

${ }^{1}$ Department of Oral Biology and

${ }^{2}$ Department of Oral Pathology,

Oral Medicine and Periodontology

Faculty of Dentistry

University of Malaya

50603 Kuala Lumpur

Malaysia

Corresponding author - R.A. Jalil

meswak which is obtained from the plant, Salvadora persica that mainly grows in the Middle East $(3,4)$. Like chewing gums, chewing sticks too may have a hydrodynamic pumping effect on plaque which might not be expected with other mechanical stimuli. In addition, chewing sticks may have a combined mechanical and chemical stimuli. Products with a hydrodynamic effect might be superior to nonhydrodynamic mechanical and chemical stimuli, although no data exist to support this hypothesis.

The objective of this study was to look at differences in the flow rate and $\mathrm{pH}$ of stimulated whole saliva (SWS) after the chewing of two differently sized commercially available meswak $(\mathbf{M})$ as opposed to chewing with an equivalent sized piece of inert material which in this case was cotton roll (CR).

\section{MATERIALS AND METHODS}

20 dental students and dental auxiliaries (aged 19 to 47 years old) volunteered to take part in this study. Since assessments were made only at the laboratory level, volunteers were accepted regardless of their age, oral and medical status. Before the start of the study all subjects received verbal information about the objective of the study and gave informed consent by filling up the forms provided to them. Participants were instructed not to consume any food and beverages two hours prior to saliva collection.

Cotton roll was chosen as an inert eliciting agent for pre-meswak samples of stimulated whole saliva. The use of cotton roll (CR) is preferred over the use of either paraffin wax or corrugated rubber since the physical property of meswak (M) as used in this study closely resembled the physical property of the cotton roll not only in its size but also in its shape. Like cotton roll too, the meswak loses its cylindrical shape a few minutes after chewing turning into a rather flat piece of chewing material. 
Saliva collection took place between 11.00 am to $12.00 \mathrm{pm}$, approximately two hours after the last intake of food or beverages. All subjects first chewed cotton roll at a constant rate of approximately one chew per second changing the chewing sides every 30 seconds for two minutes in order to achieve "maximal" stimulation. This saliva was then discarded and not used in the analysis.

The twenty subjects were then divided into two groups comprising of 10 subjects in group A and another 10 in group B. Subjects in group A resumed the chewing action specified earlier using a newly provided cotton roll (size $\|_{1} 1$ ) and the stimulated whole saliva collected in the mouth was then gently transferred into a graduated tube at the end of every 30 seconds. Subjects then switched chewing from one side of the mouth to the other every 30 seconds until approximately $4 \mathrm{ml}$ of stimulated whole saliva was collected. The time taken to collect $4 \mathrm{ml}$. of stimulated whole saliva was recorded for the purpose of calculating the flow rate according to the formula volume collected / time taken to collect the volume of saliva. This whole procedure was then repeated with a piece of meswak ( $5 \mathrm{~mm}$. diameter) using the specified chewing action until approximately $4 \mathrm{ml}$. of stimulated whole saliva was collected.

Using the same protocol, subjects in group B started by chewing on sized ${ }^{2} 2$ cotton roll after which $4 \mathrm{ml}$. of stimulated whole saliva was collected. Subjects then commenced chewing on a $10 \mathrm{~mm}$. diameter meswak until $4 \mathrm{ml}$. of stimulated whole saliva was collected. The time taken to collect the saliva was again noted. Immediately upon collection, the $\mathrm{pH}$ values of the samples were determined.

$\mathrm{pH}$ of stimulated whole saliva was determined immediately upon saliva collection via the use of a Beckman $\mathrm{pH}$ meter whilst flow rate of saliva was determined by calculating the volume of saliva collected/ time taken to collect the sample.

Statistical analysis was carried out using SPSS $8^{\text {th }}$ edition to determine mean values, standard deviations and frequency distribution. In order to explore relationships between flow rate and $\mathrm{pH}$ values of stimulated whole saliva, Pearson's correlation coefficients was used. Analysis of contrast through the use of student's t-test was also carried out in order to seek out differences between the means.

\section{RESULTS}

Table 1 presents results pertaining to the range for flow rate in stimulated whole saliva together with the corresponding mean and standard deviations for subjects in both groups $A$ and $B$. No difference in the mean value for flow rate was observed in group $\mathrm{A}$ after the two chewing regimes. In group B however, a substantial increase in mean value for flow rate was observed after the chewing of the $10 \mathrm{~mm}$. diameter meswak compared to the sized $\$ 2$ cotton roll. Analysis of contrasts carried out revealed that the difference was statistically significant at $\mathrm{p}<0.05$.
Table 2 presents results pertaining to the range for $\mathrm{pH}$ in stimulated whole saliva together with the corresponding mean and standard deviations for subjects in both groups $\mathrm{A}$ and $\mathrm{B}$. A decrease in mean $\mathrm{pH}$ was observed after the chewing of meswak compared to cotton roll. Analysis of contrasts carried out revealed that the decrease in $\mathrm{pH}$ after the chewing of meswak in both groups $\mathrm{A}$ and $\mathrm{B}$ were statistically significant at $\mathrm{p}<0.05$ and $\mathrm{p}<0.01$ respectively.

In order to explore relationships between flow rates and $\mathrm{pH}$, Pearson's correlation coefficients were calculated and presented in table 3. No associations were apparent between flow rates and $\mathrm{pH}$ values after chewing with the sized $\sharp 1, \sharp 2$ cotton roll and $5 \mathrm{~mm}$.

Table 1. Mean values and range for flow rate in stimulated whole saliva after the chewing of cotton roll and meswak with standard deviation in parentheses $(\mathrm{ml} / \mathrm{min})$

Group A, chewing of cotton roll (size \#1) followed by meswak (5 $\mathrm{mm}$ diameter)

\begin{tabular}{lcccc}
\hline Subject & $\begin{array}{c}\text { Cotton roll } \\
\text { Mean (S.D.) }\end{array}$ & $\begin{array}{c}\text { Meswak } \\
\text { Mean (S.D.) }\end{array}$ & t-test & Sig. levels \\
\hline Group A & $1.10(0.47)$ & $1.11(0.48)$ & -0.121 & $P>0.05$ \\
Range & $0.64-2.00$ & $0.43-2.00$ & & \\
\hline
\end{tabular}

Group B, chewing of cotton roll (size \#2) followed by meswak (10 $\mathrm{mm}$ diameter)

\begin{tabular}{lcccc}
\hline Subject & $\begin{array}{c}\text { Cotton roll } \\
\text { Mean (S.D.) }\end{array}$ & $\begin{array}{c}\text { Meswak } \\
\text { Mean (S.D.) }\end{array}$ & t-test & Sig. levels \\
\hline Group B & $0.91(0.20)$ & $1.18(0.25)$ & -2.314 & $P<0.05$ \\
Range & $0.67-1.33$ & $0.89-1.60$ & & \\
\hline
\end{tabular}

Table 2. Mean values and range for $\mathrm{pH}$ in stimulated whole saliva after the chewing of cotton roll and meswak with standard deviation in parentheses

Group A, chewing of cotton roll (size \#1) followed by meswak ( $5 \mathrm{~mm}$ diameter)

\begin{tabular}{lcccc}
\hline Subject & $\begin{array}{c}\text { Cotton roll } \\
\text { Mean (S.D.) }\end{array}$ & $\begin{array}{c}\text { Meswak } \\
\text { Mean (S.D.) }\end{array}$ & t-test & Sig. levels \\
\hline Group A & $7.24(0.19)$ & $7.07(0.28)$ & 2.695 & $\mathrm{P}<0.05$ \\
Range & $7.03-7.57$ & $6.71-7.58$ & & \\
\hline
\end{tabular}

Group B, chewing of cotton roll (size \#2) followed by meswak (10 $\mathrm{mm}$ diameter)

\begin{tabular}{lcccc}
\hline Subject & $\begin{array}{c}\text { Cotton roll } \\
\text { Mean (S.D.) }\end{array}$ & $\begin{array}{c}\text { Meswak } \\
\text { Mean (S.D.) }\end{array}$ & t-test & Sig. levels \\
\hline Group B & $7.40(0.20)$ & $7.09(0.26)$ & 4.266 & $P<0.01$ \\
Range & $7.05-7.13$ & $6.73-7.52$ & & \\
\hline
\end{tabular}


Table 3. Coefficients for correlation between flow rate and $\mathrm{pH}$ in whole saliva after the chewing of cotton roll (CR) and meswak (M)

\begin{tabular}{lcccc}
\hline & $\begin{array}{c}\mathrm{pH} \\
\text { CR size \#1 }\end{array}$ & $\begin{array}{c}\mathrm{pH} \\
\text { CR size \#2 }\end{array}$ & $\begin{array}{c}\mathrm{pH} \\
\text { M 5 mm. }\end{array}$ & $\begin{array}{c}\mathrm{pH} \\
\text { M } 10 \mathrm{~mm} .\end{array}$ \\
\hline $\begin{array}{l}\text { Flow rate } \\
\text { CR size \#1 }\end{array}$ & 0.466 & & & \\
Flow rate & & & & \\
CR size $\# 2$ & & 0.421 & & \\
Flow rate & & & & \\
M 5 mm. & & & -0.034 & \\
Flow rate & & & & \\
M 10 mm. & & & & $-0.637^{*}$ \\
\hline
\end{tabular}

${ }^{*} p<0.05$

diameter meswak. However, a negative association of $\mathrm{r}=-0.637$ was seen between flow rate and $\mathrm{pH}$ after the chewing of the $10 \mathrm{~mm}$. diameter meswak. This association was statistically significant at $\mathrm{p}<0.05$.

\section{DISCUSSION}

Xerostomia is the subjective complaint of oral dryness. The mucosa is dry and rough, bleeds easily and becomes readily infected with large accumulations of plaque. The tongue appears smooth and inflamed (5). At the same time, the salivary $\mathrm{pH}$ and buffer capacity in these patients are frequently depressed. In these subjects, the widely observed development of rapidly progressing rampant caries, often attacking unusual sites can be seen. Included among these are the lower anterior teeth, the cusps and cervical regions of the teeth. In these areas, the teeth may have a white opaque appearance due to demineralization. Cariogenic organisms such as Streptococcus mutans, Lactobacilli and Actinomyces viscosus become dominant, while Streptococcus sanguis, Streptococcus salivarius, Fusobacteria and Neisseria show a decrease $(6,7)$.

Many commonly used medications predispose to xerostomia. However, the nature and severity of the disease for which these drugs have been prescribed may preclude their removal. The objective of symptomatic treatment of xerostomia is to increase the overall wetness of the oral tissues. The success of these interventions is dependent on the degree to which the salivary glands are able to respond to various stimuli.

In patients with viable, residual salivary gland tissue, it may be possible to stimulate the flow of their saliva. Such patients are referred to as "responders". Where this is not possible, in "non-responders" treatment must be designed to provide moisture to the oral tissues by other means.

Although salivary secretion has been the subject of several quantitative and qualitative investigations, the results obtained have been contradictory. This lack of agreement may be explained by differences in the experimental design. The rate of secretion and the chemical composition of saliva found in a given investigation depend on the method of measurement, the duration of sampling, the hour of sampling, the interval since last meal, the age, sex and mental state of the donor. In order to diminish the effect of some of the general factors, the present investigation was performed where the method of collection, posture of the person studied, time of last meal had been standardized as far as possible.

Circadian variations in some salivary components have previously been demonstrated in both men and experimental animals. Dogon and co-workers (8) showed 24 hour variation in the secretions of both chloride and thiocyanate. Ferguson and Fort (9) examined in detail the circadian variation in flow rate and concentrations of sodium, potassium, calcium, chloride, total and inorganic phosphate, nitrogen, protein and total carbohydrate in unstimulated human submandibular saliva and found changes in concentrations of some salivary components due to circadian variation. Henceforth, the effect of circadian variation was also taken into consideration in the design of the experiment since circadian rhythm is not only known to affect salivary composition but to some extent, flow rate as well $(10,11)$.

The purpose of this study was to investigate the immediate term effect of chewing two differently sized commercially available meswak on flow rate and $\mathrm{pH}$. The result of this study seemed to indicate that the 10 $\mathrm{mm}$. diameter meswak is more effective in stimulating salivary flow when compared to either the $5 \mathrm{~mm}$ meswak or the cotton roll.

Studies have shown that subjects with low caries tended to have higher mean flow rates of unstimulated parotid saliva compared to those in the higher caries group $(5,12)$. The most comprehensive study was conducted by Shannon and Terry (13) who measured parotid flow rate without exogenous stimulation in 3,786 healthy young adult males. In the group with 0 to 10 DMFS there was a significantly higher flow rate $(0.041 \mathrm{ml} / \mathrm{min})$ than in all the other subjects $(0.037 \mathrm{ml} /$ min) with DMFS from 10 to more than 50.

Any consideration of flow rates cannot be divorced from that of $\mathrm{pH}$ and buffering. With an increase in secretion rate, there is an increase in both $\mathrm{pH}$ and buffering capacity (16) and the increase in flow rate will tend to remove carbohydrate from the mouth. Continued stimulation of saliva following a meal or snack, example by chewing sugar free gum raises plaque $\mathrm{pH}$ and thus reduces demineralization and favors demineralization.

In this study, with regards to $\mathrm{pH}$, both sizes meswak had the potential of decreasing the $\mathrm{pH}$ of stimulated whole saliva. This observation was also seen in an earlier study by Gazi et al 1992 (15). Although the decrease in $\mathrm{pH}$ were statistically significant at $\mathrm{p}<0.05$ for subjects in group $A$ and at $p<0.01$ for those in group B, the range of values registered after the chewing of meswak were still higher than the "critical $\mathrm{pH}$ ". It has been calculated that saliva remains saturated until the $\mathrm{pH}$ falls to about $5.85-5.20$ i.e. the so called "critical pH" below which enamel dissolves (5). 
When association were explored between flow rate and $\mathrm{pH}$, a negative association was found in both groups of subjects after the chewing of meswak. However the association was only statistically significant in group $\mathrm{B}$ at the $\mathrm{p}<0.05$. These findings could be attributed to the chemical content of meswak since meswak has been found to contain fluoride, silica, alkaloids, essential oils, resins, gum and atraquinones. These substances could have either directly or indirectly contributed to the decrease in $\mathrm{pH}$ as seen in this study. Results of this study seemed to indicate that the thicker meswak (10mm. diameter) contributed more towards decreasing the $\mathrm{pH}$ of saliva compared to the thinner meswak.

A positive association was seen between salivary flow rate and $\mathrm{pH}$ in this study after the chewing of cotton roll. However, the positive association seen did not reach levels of statistical significance. The positive association seen between flow rate and $\mathrm{pH}$ after the chewing of cotton roll is in agreement with earlier investigations (14) that used inert stimuli for example rubber bands or paraffin wax.

Mastication is the normal, physiological stimuli for salivation. Patients should therefore be encouraged to consume foods which require vigorous chewing. Stimulation of the glands through mastication for example via the use of chewing sticks may be beneficial in terms of promoting clearance of food from the mouth and may help by causing an increase in the unstimulated flow rate on a long term basis.

Further studies should be carried out on patients with xerostomia in an attempt to increase their salivary secretion rate and decrease the feeling of mouth dryness by chewing meswak. When testing a saliva-stimulating product such as the meswak, it is important to select a random sample from an appropriate population that is, subjects who have xerostomia but who also have the ability to produce some saliva. There is obviously no point in testing the effect of chewing sticks on saliva secretion rate in patients who are unable to increase their saliva secretion on stimulation. In individuals with normal salivary flow, it is doubtful whether products that stimulate salivary flow would benefit the oral soft tissues. In individuals with decreased levels of salivary function, products that can increase the rate of salivary flow may prove beneficial, depending on the cause and extent of the salivary gland hypofunction.

In summary, results of this study seemed to suggest that plants used as chewing sticks may have the potential of increasing the flow rate of saliva and thus the use of meswak may be beneficial to those with reduced salivary secretion. Both sized meswak appeared to contribute to a reduction in the $\mathrm{pH}$ of saliva. However the range of values registered after the chewing of meswak did not reach the "critical $\mathrm{pH}$ " whereby demineralisation will follow. Further studies have to be carried out to ascertain the therapeutic benefits of using meswak as an anti-plaque agent.

\section{ACKNOWLEDGEMENTS}

We would like to thank Professor Dr. Zubaidah Abdul Rahim, Head of the Department of Oral Biology for her advice throughout the course of this study, Dr. Siti Lailatul Akmar and Dr. Sushil Kaur for all technical help, Mr. and Mrs. John W. Johnson of Doha, QATAR for painstakingly selecting and providing us with three different sets of meswak and finally, acknowledgement is made to all the volunteer subjects from the Faculty of Dentistry, University of Malaya for participating in this study.

\section{REFERENCES}

1. Edgar WM, O’Mullane DM. Saliva and dental health. In clinical implications of saliva and salivary stimulation for better dental health in the 1990s. Report of a consensus workshop held at Ireland, 1989; 89-95.

2. Olsson H, Spak C-J, Axell T. The effect of a chewing gum on salivary secretion, oral mucosal friction and the feeling of dry mouth in xerostomic patients. Acta Odontol Scand 1991; 49: 273-9.

3. Evenari M, Gutterman Y. Some notes of Salvadora persica in Sinai and its use as a toothbrush. Flora 1973; 162: 118-25.

4. Perteres RA. Curious Arabo-Slamic and NeoAfrican cultural element: The chewing stick used for polishing the teeth. J Agric Trop Bot Appl 1974; 21: 1-3.

5. Speirs RL. Saliva and Dental Health (1). Dental Update 1984; 11(9): 541-52.

6. Epstein JB. The role of Saliva in Oral Health and the causes and effects of Xerostomia. J Canad Dent Assoc 1992; 58(3): 217-21.

7. Bertram U. Xerostomia. Acta odontol Scand 1967; Suppl. 49: 25.

8. Dogon IL, Amdur BH, Bell K. Observations on the diurnal variation of some inorganic constituents of human parotid saliva in smokers and non-smokers. Arch Oral Biol 1971; 16: 95-107.

9. Ferguson DB, Fort A. Circadian variations in human resting submandibular saliva flow rate and composition. Arch Oral Biol 1974; 19:47-55.

10. Jalil RA. Daytime variation and reproducibility of salivary defence factors in resting whole saliva. In: Proceedings of the $19^{\text {th }}$ Malaysian Biochemical and Molecular Biology Society Conference 1994; Extended abstract 68 . 
11. Jalil RA, Ashley FP. Daytime variation and reproducibility of salivary defence factors in stimulated parotid saliva. In: Book of Programmes of the $18^{\text {th }}$ Annual Conference of the Malaysian Biochemical Society 1993; Abstract no. 7E.

12. Mandel D., The functions of Saliva. J Dent. Res 1987; 66 (Special issue): 623-27.

13. Shannon IL, Terry JM. A higher parotid fluid flow rate in subjects resistance to caries. J. Dent Med 1965; 20: 128-32.
14. Ericsson Y. Clinical investigations of the salivary buffering action. Acta Odont Scand 1959; 17: 13165 .

15. Gazi MI, Davies TJ, Al-Bagieh N, Cox, SW. The immediate- and medium-term effects of Meswak on the composition of mixed saliva. J Clin Periodontol 1992; 19: 113-17. 